\title{
Food Price Volatility in Ethiopia: Public Pressure and State Response
}

\section{Tassew Woldehanna and Yisak Tafere}

\begin{abstract}
The global market, variable agricultural production and irregular trading practices have marked food price volatility in Ethiopia over the last decade. However, the recent decline in global prices of food and fuel, coupled with state intervention in managing the supply of consumer goods, have brought some stability to food prices in 2014/15. While the safety net and price control measures could help mitigate the aggravation of impacts of food price increases on poor families, a more comprehensive food security approach is necessary. The article argues the importance of enhancing the purchasing power of the people.
\end{abstract}

\section{Introduction}

Over the last decade, the Ethiopian economy showed steady growth. On average the gross domestic product (GDP) growth between 2001 and 2014 was 9 per cent, with the highest growth registered between 2003 and 2010, at 11.4 per cent per annum. The per capita income was $£ 83$ (US\$129) per person in 2001, and grew to $£ 408$ (US\$632) per person in 2014 (MoFED 2014). According to a recent report by the Ministry of Finance and Economic Development, poverty reduction, improvements in food security, and children's progress in education and nutritional achievements have been driven by this economic growth and growth in the incomes of those below the poverty line (MoFED 2013a). This usually results from one of two channels - growth in incomes or redistribution of benefits to people living in poverty. Economic growth has played the most important role in poverty reduction over the past 15 years. In urban areas, infrastructural development (e.g. cobblestone construction) and its use of labour has increased the incomes of many of those living in poverty.

Despite the general improvements in living conditions for Ethiopians, around 25 million people in the country ( 29 per cent of the population) live below the nationally defined poverty line (MoFED 2012, 2013a). Chronic malnutrition is very high at 40 per cent (CSA 2014). In recent years, inflation has been a major shock. National statistics (MoFED 2013b, 2014) show that food price volatility in Ethiopia started in 2003 and the average food inflation rate rose and fell sharply (see Table 1 and Figure 1). In 2014, food prices were high while food inflation was in single digits. The main objective of this article is thus to examine how people and government have dealt with the extraordinary levels of food price volatility in Ethiopia in recent years.

This article draws on a three-year qualitative study carried out in two communities in Ethiopia as part of the Life in a Time of Food Price Volatility project. ${ }^{1}$ Data were collected in 2012, 2013, and 2014 in the month of August. The urban study area is a wored $a^{2}$ in a Kolfe Keraniyo sub-city of Addis Ababa, where people earn their living as traders, civil servants, artisans, vendors, house renters, grain sellers, vegetable growers and daily labourers or are pensioners. The main sources of employment in the community are wood and metalwork, construction, tailoring, food processing, cobblestones and casual labour. The majority of the residents of this area are poor. The rural site is a village in Adami Tulu Woreda, Eastern Zone of Oromia Region. Nearly all people in the community are poor and earn their living through rain-fed farming while some are involved in petty trade and wage labour. In seasons of poor rains many households find it hard to meet their food needs.

Data collection methods included focus group discussions and interviews with key informants and householders. In each community we organised eight focus groups, 11 key informant interviews, and 22 household case studies. The focus group discussions covered diverse groups of people from each community, with a focus on women, youth, mixed groups (gender, age, occupation, religion, 


\begin{tabular}{|c|c|c|c|}
\hline \multirow[b]{2}{*}{ Year } & \multicolumn{3}{|c|}{ Inflation } \\
\hline & Food & Non-food & General \\
\hline 2000 & -5.5 & 4.5 & -1.5 \\
\hline 2001 & -14.4 & 0.3 & -8.2 \\
\hline 2002 & 2.5 & 0.1 & 1.7 \\
\hline 2003 & 27.7 & 1.8 & 17.8 \\
\hline 2004 & 3.0 & 3.9 & 3.2 \\
\hline 2005 & 13.7 & 7.2 & 11.7 \\
\hline 2006 & 14.3 & 11.5 & 13.6 \\
\hline 2007 & 22.1 & 11.8 & 18.0 \\
\hline 2008 & 60.3 & 22.0 & 44.4 \\
\hline 2009 & 3.3 & 18.2 & 8.5 \\
\hline 2010 & 1.7 & 19.2 & 8.2 \\
\hline 2011 & 38.4 & 24.7 & 33.2 \\
\hline 2012 & 28.4 & 19.4 & 24.1 \\
\hline 2013 & 26.9 & 18.4 & 22.9 \\
\hline 2014 & 6.7 & 11.6 & 8.9 \\
\hline
\end{tabular}

Source MoFED (2013b, 2014). National income account estimates.

etc), and those engaged in grain production (rural) and traders (urban). Key informants included local administrators and other government officials, farmers, traders, consumers, and representatives of local organisations. Household interviewees were selected for diversity in economic status, family background and types of livelihoods (farmers, daily labourers and traders).

\section{Food price volatility}

Study respondents made it clear that there had been a noticeable price increase of food items in September 2007. Food prices increased remarkably during the Ethiopian Millennium festive season. In the urban areas the major change was an increase in the rent of housing, mainly because guests coming from abroad in numbers for the festivities raised the demand. In the rural areas rainfall failure, an increase in the price of inputs (fertilisers, selected seeds, pesticides), and the profit-seeking grain traders were blamed for the rapid price rises. After 2007 prices continued to rise, increasing even more rapidly between 2011 and 2012 when, in one year, farmers in Adami Tulu explained that the price of a quintal of selected wheat seeds increased from 860 birr (£27) to 1,130 birr (£35), selected maize seeds from $800 \operatorname{birr}(£ 25)$ to $1,400 \operatorname{birr}(£ 44)$ and fertilisers from 1,120 birr (£35) to 1,500 birr 


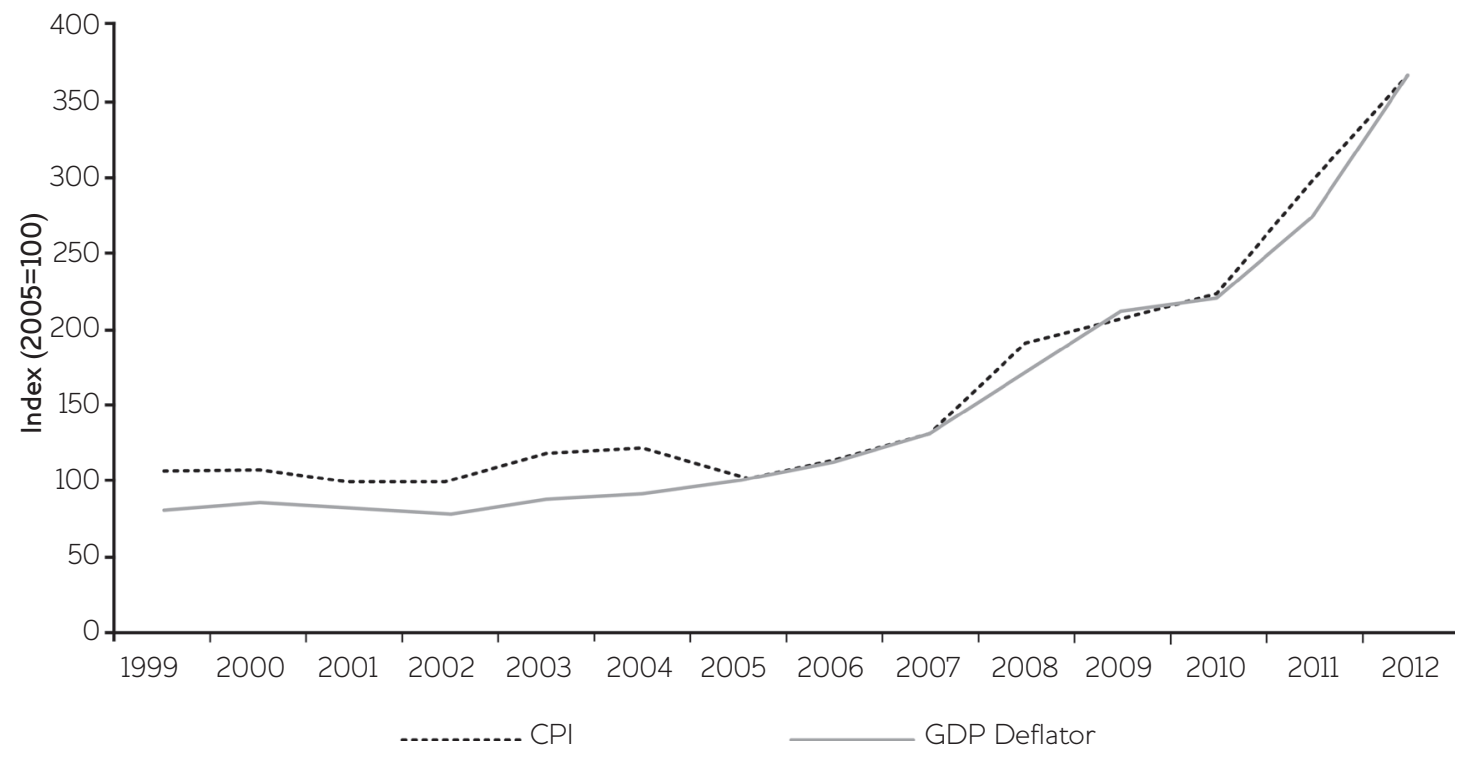

Source MoFED (2014). National income account estimates.

(£47) in 2011 and 2012, respectively. Despite an increase in harvest in some years, the price rarely declined, mainly because of high costs of inputs and increased urban demand for food grains. However in 2014, with the decline in the price of oil in global markets price of inputs, notably fertiliser, declined significantly and food prices appeared to stabilise.

The other feature of food price volatility in the study communities is its seasonality. Food items get cheaper in autumn (November-January) but become very expensive during the summer (July-October). Autumn (October-December) is a harvest season when most farmers collect their harvest and make it available for market. During this season, poor people in rural areas have some produce for consumption and rarely go to market to buy grains and the urban population can buy food items for lower prices than in other seasons. During the harvest season farmers sell their products in bulk because they need some money to buy non-food necessities, so prices fall rapidly. Mrs H., a 30-year-old farmer ${ }^{3}$ from Eastern Oromia summarised this by saying:

Farmers usually sell their grains immediately after harvest season in November or December... They need to cover costs of inputs, tax, and school expenses for children, clothes, spices, etc. Food crops are also sold to cover social contributions such as Iddir, ${ }^{4}$ marriage ceremonies and other festivities. As the result, the price of food crops declines immediately after the harvest season.
The biggest outlay for farmers at this time is to pay the costs of improved seed, fertilisers and pesticides that they obtained on credit during the preceding summer. Thus, they are obliged to sell their produce at a much lower price during these seasons to meet their obligations. For example, in the rural community farmers reported that in 2012, they sold a quintal of teff for 600 birr in the autumn and rebought it for 1,600 birr in the summer. Many producers become consumers during the summer.

\section{Ways of coping}

People respond to food price rises in different ways. Most work hard to earn more. In the context of limited job opportunities, very few succeed in generating more income, however, so they also change their consumption behaviour.

\subsection{Reduced consumption}

The first thing people do to cope with the effect of higher food prices is to reduce the quantity and quality of food they are eating. Respondents reported that when there is food shortage, they skip some meals or eat low-quality food. A 24-year-old farmer ${ }^{5}$ from Eastern Oromia explained:

We eat insufficient and poor-quality food. The household should have eaten four times a day. However, we could not eat even three times a day. The variety was very good in winter but now [summer] the variety has declined and we mainly eat bread with cabbage. We rarely prepare shiro wot ${ }^{6}$ or eat meat or vegetables. 
Even children are not encouraged to eat enough. A 30-year-old mother ${ }^{7}$ speaking at a focus group discussion in the Addis Ababa site said:

In the past, children were welcomed to eat as much as they can, but now they are not encouraged to consume more food. Instead, their mothers get angry when the children ask for food and say Afer bila! [Eat the soil!'].

A 40-year-old poor woman ${ }^{8}$ who feeds seven members of her family by selling enjer $a^{9}$ and dried herbs for cooking explained how her family has been affected:

\section{We are suffering from food shortage. When I do not have cooking oil, sugar or even shiro, we eat only a piece of bread with no stew... If we get food today, we may not have any tomorrow. If we eat in the morning, we may not eat in the afternoon... we do not eat teff enjera ${ }^{10}$ anymore, but rather a piece of bread because we buy [wheat] flour from the kebele ${ }^{11}$... We no more use food oil or onions for stew... when I take 100 birr to market to buy food items it buys the equivalent of what I used to buy for 1 birr in the past.}

She buys teff and prepares enjera for sale, but her family members do not eat it because they have to sell it to earn some profit. They instead consume bread, which is cheaper.

\subsection{Alternative consumption: processed food}

Over the study years we learned that people have increasingly been resorting to processed food. It started as snacks, but nowadays fast food is becoming the regular meal for many. In the urban community boiled and roasted maize, boiled sweet potatoes, samosa, potato chips, roasted biscuits, coffee and various types of roasted grains $(k o l o)$ are sold at the roadside. Many of the young, students, taxi assistants, shoe shiners, drivers and daily labourers consume these filling, but often less nutritious and sometimes dangerous foods as their main meal.

In the rural community people sell both traditional and modern pre-prepared foods and drinks: they may sell enjera with or without wot (stew), fish soup, farso (local beer), keneto (a drink made from barley), shemeta (non-alcoholic beer), or they sell packaged biscuits, juice and soft drinks outside their houses. Young and adult men from the community and migrant labourers who work on neighbouring irrigation farms prefer these fast foods as they are easily accessible on the street and are both tasty and cheap. There are some concerns associated with processed food, mainly related to hygiene and sanitation. The food is prepared on the roadside with no shelter, exposed to sun and dust. Many also doubt the quality of the cooking oil used. Rural householders report that it is much easier to buy enjera from the local shops and serve their guests at home. It has reduced the burden on the housewives. They want to use their labour in working on the farms instead of preparing food at home.

The study shows that people on low incomes are responding to high and volatile prices by changing their consumption habits and also that families generally find it hard to address the problem on their own. They feel that they were overwhelmed not only by the food price shocks of 2007 and 2011, but by their aftermath. Ultimately, they look for the state to help.

\section{Public pressure and state response}

Following sporadic food crises over the decades, the Ethiopian government has developed an increasingly efficient institutional readiness to respond to hunger. Since 2005 it has provided support to areas deemed food insecure through its Productive Safety Net Programme (PSNP) during the hunger periods, usually in spring and the summer. After 2008, the PSNP was complemented by the other food security programmes (OFSPs) and the Household Asset Building Programme (HABP). An impact assessment (Berhane et al. 2011) showed that the PSNP had improved household food security of PSNP beneficiaries by 1.05 months, while beneficiaries of all three programmes (HABP, OFSP and PSNP) have improved food security by 1.53 months; holdings of livestock units have increased by 0.38 tropical livestock units (TLUs); and the number of children's meals consumed increased by 0.15 in the lean season. For recipients, access to the PSNP/ OFSP/HABP has increased the likelihood of using fertiliser by nearly 20 per cent, and of investing in stone terracing by 13 per cent (ibid.). Overall, the study found improvements in household assets, incomes, food production and nutrition as a result of these food security programmes. Moreover, the World Bank study (Woldehanna, Tsehaye and Hill 2014) indicated that the PSNP was able to reduce the national incidence of poverty by 2 per cent in 2010/11. However, the programme has shortcomings. It is mainly rural and targets farming households. It does not include the urban poor. Secondly, it responds to food insecurity caused by natural calamities, mainly production decline due to rain shortage. This means that it is not aimed at life challenges that emerge as a result of food price volatility. The state has come under pressure from the public to intervene. 


\subsection{Public pressure}

The study shows that many people do not ask for food from the government because they 'know' that it does not provide. To assist those who do have the courage to ask for help, the local official tends to encourage people to deal with their own situation. She or he may also coordinate with non-governmental organisations (NGOs) that might be ready to respond to the aid requests. In 2013, for example, the head of Women, Children and Youth Affairs (WCYA) for the urban study site said: 'There are also people who apply to my office for some kind of food aid. I have told them that as food aid does not bring sustainable solution to their food crises, they have to work hard and seek other solutions by themselves. ${ }^{12}$

The state assumes that by creating job opportunities and service provision for the public, people will enhance their buying capacity. In urban areas, officials are concerned with creating job opportunities such as working on cobblestone, road construction and condominium housing construction for youth, and in rural areas giving training and supply of modern agricultural inputs to improve productivity. There are no institutional structures that respond to those who go hungry as a result of food price hikes. Thus people on uncertain incomes continue to press the state to respond to the new situation. The pressure emanates from all sections of the population, including government officials. A Women's Affairs officer ${ }^{13}$ from the rural community stated: 'The government is responsible. Next to God, the government is considered as father of its citizens and father does not remain silent when his children are hungry.'

Many of our respondents argue that the new economic challenges are emanating from poor market regulation and they believe that price stability can only be achieved through the intervention of the state. One farmer ${ }^{14}$ from Eastern Oromia asked: 'Why does the government prefer to keep silent, not help the poor and the most disadvantaged ones who are suffering a lot from the increase in the price of food items?'. This is echoed by many from both the rural and urban communities.

\subsection{State response}

How does the state intervene? It has responded with efforts towards immediate price control and institutional arrangements to supply consumer goods at cheaper prices and provide legal protection to consumers.

\section{Price controls}

In 2010, the Federal Ministry of Trade made attempts to control prices, first by prohibiting traders from hoarding food items in their stores, and second by enforcing fixed prices on essential foodstuffs. Traders contravening the regulations had their licences revoked. Some were also taken to court and penalised. Although it seemed to relieve the customers temporarily, it did not work out well and traders continue to store goods and the consequent shortages became severe. The state then promoted consumers' associations in every urban locality and Farmers' Union shops in rural areas. Reviving a practice that was first used during the Derg regime of 1974-91, when in every kebele community shops (hibret suk) supplied inhabitants with necessary consumer items, this new process began in 2007 in urban areas, but only started operating effectively in the last two years.

Since 2013, there has been a rapid expansion of these cooperative shops in every kebele in Addis Ababa, including the study site. Former kebele public recreation centres have now been transformed into cooperative shops and butcheries serving the public. The state-run Ethiopian Grain Trade Enterprise (EGTE) now buys grains during the harvest season at a fair price (not to harm the farmers) and resells it at marginal profit. This helps ease the seasonalityrelated volatility of food prices that has been affecting farmers and consumers for years. It also supplies consumer goods to the cooperatives to sell to the public at reasonable prices. For instance, sugar is produced locally by state factories and is channelled to local consumer cooperatives mainly through the state-owned Ethiopian Trading Enterprise (ETE). ETE also imports and supplies edible oil and agricultural inputs to the cooperatives.

Reduced fertiliser prices and the greater reach of government subsidy programmes has produced a change that has been felt by local people. For example, in 2014, a farmer ${ }^{15}$ from the rural community said, 'This year, the price of fertiliser decreased from 1,000 birr to 600 birr because the Farmers' Union brought it to the community and reduced transport and profit the traders used to benefit from.' Another farmer confirmed:

\section{[T] he union provided chemical fertilisers and improved seeds. I received these items during the farming season (in June and Fuly). We also bought sugar and food oil from the consumers' cooperatives. The price of both agricultural inputs and consumer goods are fair and sometimes cheaper.}

As indicated in Figure 2, in our study sites we observe that the price of some food items (sugar, teff and maize) and inputs (fertilisers) decreased in 2014, but wheat and cooking oil increased. In general, 


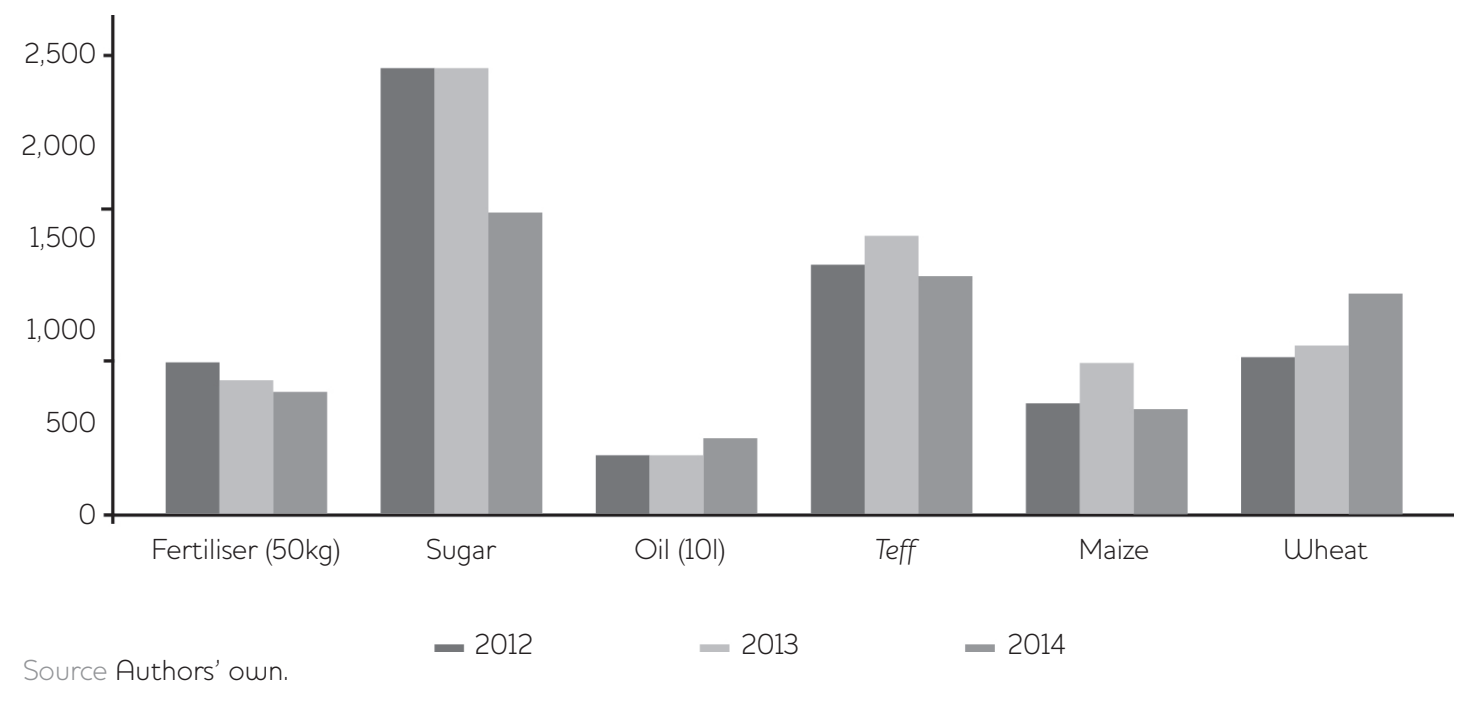

it seems that the overall food price volatility is declining and shows stability this year, as seen from the aggregate figure (see Table 1).

While state interventions have been useful, it has been difficult to meet all the demands of millions of farmers and consumers. The institutional arrangements at federal and local levels are not strong enough for full implementation of the programme. Moreover, there are seasonal shortages of food items at market. Farmers are still forced to sell their produce during the harvest season at low prices to meet their obligations for land tax, school expenses and debts for fertilisers, pesticides and seeds. Respondents, especially farmers, have suggested that the state should help them in rescheduling the payment of taxes and debts to avoid these seasonal effects.

\section{Legal protection}

Recognising the limitation in meeting the needs of consumers, the state has adopted a legal protection that would promote fair trade by the business community. To control high food price volatility, the Ethiopian government issued a decree of Trade and Consumers' Protection Authority in $2010 .{ }^{16}$ The objective is to accelerate economic development by protecting consumers and the business community from unfair market practices and misleading market conduct. Consumer protection is implemented through the provision of sufficient and accurate information on the quality and type of goods. It could help consumers to buy goods selectively and promotes their right to report any complaints to the Trade Practice and Consumers' Protection Authority. The proclamation also ensures consumers' eligibility for compensation in case they face unfair trading conditions.

During the 2012 fieldwork, the Trade Practices and Consumers' Protection Authority was in the process of building its capacity. It was only established in the capital. Soon, it started promoting its objectives through the media and through educational programmes and trainings. It also began suing traders who violated consumers' rights. In 2014, we found that the Authority was taking traders to court for unlawfully hoarding consumer goods or for selling poor quality food items. During our discussion with stakeholders, consumers have welcomed the move and they have been collaborating in reporting actions of any faulty traders to the authorities.

\section{Promoting economic growth}

It is clear that food price volatility cannot be eliminated through price control alone. While legal protection and supply of consumer goods through cooperatives remains an important short and midterm riposte, the ultimate solution lies in enhancing productivity and the purchasing power of the people.

In urban areas, local authorities were engaged in creating job opportunities and advising the public how to save. The federal government also instituted a salary increment for civil servants in 2014 and provided them with free public transport. In rural areas local officials advised farmers to use their yields properly in both consumption and selling, as explained by a kebele leader: ${ }^{17}$ 
We tell farmers not to sell their crops unless they are sure that they have reserved enough food for the family. Moreover, people should increase productivity. If they are able to produce surplus, they can cope with the food price increase. To increase productivity, farmers are trained and advised to use improved seed, fertilisers and pesticides.

Poor farmers are sceptical. The majority do not have enough land and oxen to increase productivity. Others do not have the financial capacity to buy the requisite modern inputs. Land is also, as the farmers put it, 'addicted to fertilisers'. They know that they should reserve food for their family, but they are forced to put their families second to their debts and tax obligations. They remain vulnerable to price volatility and look for continued support from the state.

\section{Concluding remarks}

The global market, variable agricultural production and irregular trading practices have marked food price volatility in Ethiopia over the last decade. The recent decline in global prices of food and fuel coupled with state intervention in managing the supply of consumer goods have brought some stability in food prices in the last year. Price control, supply of food items at a fair price in every neighbourhood, consumer protection, salary increase and free public transport for civil servants appears to have made some difference to wellbeing. But as these measures are limited in scope, there are still many poor people struggling to get by in everyday life.

While short-term intervention could help mitigate the aggravation of impacts of food price increases on poor families, more engagement for comprehensive food security is necessary. The second national Growth and Transformation Plan (GTP2), which is about to be launched, advocates for such engagement (NPG forthcoming). The Life in a Time of Food Price Volatility study provides

\section{Notes}

1 www.ids.ac.uk/project/life-in-a-time-of-foodprice-volatility.

2 The second local administrative tier above kebele.

3 Eastern Oromia, 2012.

4 Iddir-funeral savings group.

5 Eastern Oromia, 2013.

6 Shiro wot is a dish made of chickpeas, spices and butter.

7 Addis Ababa, 2012.

8 Addis Ababa, 2012. some practical insights as to the realities of grassroots-level food security issues that could inform the implementation of GTP2. It demonstrates how households are dealing with ongoing food price volatility caused by global changes and local realities. In our study sites people have some hopes for the government's recent move to enhance productivity and youth employment. However, the study shows that for farmers rising costs and the timing of payment of debts and taxes remain significant hurdles. Within the contexts of global price increases of fuels and fertilisers, reducing prices could be difficult. Providing inputs with improved credit and savings facilities and arranging appropriate repayment times could help to smooth food prices.

The immediate response to severe food price volatility has been helpful to many Ethiopians. People encouraged by the outcome of the state response so far are looking for further interventions that will help them increase their purchasing power and reduce uncertainty. The job opportunities created so far are appreciated, but are not sufficient to enhance the purchasing power of the people in a sustainable manner. There is more to be done. It is interesting to note that a government which came to power by defeating the previous state that had pursued a command economy, may end up taking the same economic route. By pursuing a free-market economy, the state has made possible significant economic growth over the last decade. But it seems that it is now caught between its policy of free-market-based growth on the one hand, and responding to public demand by intervening in the market in ways that redistribute wealth, on the other. Would this be a developmental state in the making in Ethiopia? We, as researchers, would like to see how this works in the future and how it affects the study communities in particular and the country in general.

9 Enjera is fermented bread made from teff flour, an Ethiopian grain.

10 Teff enjera - see endnote 9.

11 Kebele - a village or a local administrative structure in a town.

12 Addis Ababa, 2013.

13 Eastern Oromia, 2013.

14 Eastern Oromia, 2013.

15 Eastern Oromia, 2013.

16 Proclamation No. 685/2010.

17 Eastern Oromia, 2012. 


\section{References}

Berhane, G.; Hoddinott, J.; Kumar, N. and Taffesse, A. (2011) The Impact of Ethiopia's Productive Safety Nets and Household Asset Building Programme: 2006-2010, Washington DC: International Food Policy Research Institute (IFPRI)

CSA (Central Statistical Agency of Ethiopia) (2014) Ethiopia Mini Demographic and Health Survey Report 2014, Addis Ababa: CSA

MoFED (Ministry of Finance and Economic Development) (2014) Brief Note on the 2006 (EFY) National Accounting Systems (NAS) Estimates: The Major Results of the 2006 GDP Estimates, Addis Ababa: MoFED

MoFED (Ministry of Finance and Economic Development) (2013a) Development and Poverty in Ethiopia: 1995/96-2010/11, Addis Ababa: MoFED
MoFED (Ministry of Finance and Economic Development) (2013b) National Economic Accounts Statistics of Ethiopia: Estimates of the 2010/11 Base Year Series (2003 Ethiopian Fiscal Mear), Addis Ababa: MoFED National Economic Accounts Directorate

MoFED (Ministry of Finance and Economic Development) (2012) Ethiopia's Progress Towards Eradicating Poverty: An Interim Report on Poverty Analysis Study (2010/11), Addis Ababa: MoFED NPC (National Planning Commission) (forthcoming) 'Second Growth and Transformation Plan (2015/16-2019/20)', Federal Democratic Republic of Ethiopia: NPG

Woldehanna. T.; Tsehaye, E. and Hill, R.V. (2014) 'Commitment to Equity Fiscal Incidence Analysis for Ethiopia', mimeo, Washington DC: World Bank 